\title{
USING WORD GRID GAMES TO INCREASE THE VOCABULARY ACHIEVEMENT OF THE SECOND GRADE STUDENTS OF SMP N 8 PEKANBARU
}

\author{
Sandi Ade Hidayat ${ }^{1}$ and Effendy Gultom² ${ }^{*}$ \\ ${ }^{1}$ Training and Education Faculty, Riau University Graduate, Pekanbaru \\ ${ }^{2}$ English Lecturer, Teachers' and Education, Riau University, Pekanbaru \\ Email :effendygultom@gmail.com
}

\begin{abstract}
Vocabulary plays an important role in learning a foreign language. It is an element that links the four language skills: speaking, listening, reading and writing. In order to communicate well in a foreign language, students need to have sufficient vocabulary. After that, they need to understand the structure, function, etc. Toenrich theirvocabulary.There are many useful approaches can be used. One of them is using games.
\end{abstract}

Keywords : word grid games, vocabulary achievment

\section{INTRODUCTION}

Word grid game is one of the language games that are used to improve the students' vocabulary achievements. It is designed by Allan Turroff and tradmarked by Parker Brothers and Hasbro.

In playing word grid games, the player searches some words that can be constructed from the letters sequentially adjacent cubes, where "adjacent" cubes are those horizontally, vertically or diagonally neighboring. Words must be at least three letters long. Each players records all the words which are found in the cubes by writing them on a seperate sheet of paper.

\section{METHODOLOGY}

\section{The Presentation of the Pre-Test}

Before testing the students, the researcher needs to try out the tests in order to be valid and reliable. In the result of the pre-test, the writer found out that the average score of the pre-test was 54.44. Meanwhile, the median was 58. Below is the students' pre-test and their level of ability determined by Haris, David. P.

Table 1: The Students' Pre-Test

\begin{tabular}{cccc}
\hline Score Range & Level of ability & Frequency & Percentage \\
\hline $81-100$ & Excellent & 0 & $0 \%$ \\
$61-80$ & Good & 7 & $19,44 \%$ \\
$41-60$ & Mediocre & 19 & $52,78 \%$ \\
$21-40$ & Poor & 9 & $25,00 \%$ \\
$0-20$ & Very Poor & 1 & $2,78 \%$ \\
\hline
\end{tabular}


Based on the diagram above, we can see that:

- $\quad 1$ student (2,78\%) is categorized into very poor level

- 9 students (25\%) are categorized into poor level

- 19 students are categorized into mediocre

- 7 students (19.44\%) are categorized into good level

- No body reached the excellent level.

The pre-test result was dominated by the scores ranging from 41-60. Meanwhile, the minimum criterion of achievement of the English subject at SMPN 8 Pekanbaru is 6.50. That means that most students got problems with vocabulary.

\section{RESULT AND DISCUSSION}

\section{The Result of Post-Test in the First Cycle}

After giving the pre-test, the writer the writer designed a treatment to sole the students' problem in vocabulary achievement by using word grid game. After giving treatnt, the writer gave pos-test to the students at the forth meeting. In the result of post-test in the first, the writer found that the average score of the posttest was 63.78. Meanwhile, the median of the class was 64. The description of the post-test is presented as follows:

Table 2: The Result of the Students' Post-Test of the First Cycle

\begin{tabular}{cccc}
\hline Score Range & Level of ability & Frequency & Percentage \\
\hline $81-100$ & Excellent & 2 & $5.56 \%$ \\
$61-80$ & Good & 21 & $58.33 \%$ \\
$41-60$ & Mediocre & 10 & $27.78 \%$ \\
$21-40$ & Poor & 3 & $8.33 \%$ \\
$0-20$ & Very Poor & 10 & $0 \%$ \\
\hline
\end{tabular}

The table above presents that there were:

- 2 students reached the excellent level

- 21 students reached the good level

- 10 students reached the mediocre level

- 3 students reached at poor level

- No student isthe very poor level

To analyze the data the first cycle can be compared between pre-test and the post-test. The description of the differences between the pre-test and the post-test presented as below: 
Table 3General description between pre-test and post-test

\begin{tabular}{cccccccc}
\hline Test & sample & Mean & $\begin{array}{c}\text { Standard } \\
\text { Deviation r }\end{array}$ & $\begin{array}{c}\text { Standard } \\
\text { Error }\end{array}$ & d.f & T test & t critical \\
\hline Pre-test & 36 & 54.44 & 4.95 & 0.825 & 35 & 11.175 & 2.457 \\
$\begin{array}{c}\text { Post-test of } \\
\text { first cycle }\end{array}$ & & 63.67 & & & & & \\
\hline
\end{tabular}

Table 3 above shows that after conducting the first cycle, the average score of the test increases from 54.44 to 63.67. It shows an improvement from the pre-test which is classified into average level to become good level at the post-test of the first cycle.

From the result, it can be inferred that the students' scores has increased. However, there were a half of the students did not reach the minimum criterion of achievement (KKM) because the average score only reach 63.78 and the median is 64 . So, the writer continued the research to the second cycle.

\section{The Result of Observation in the First Cycle}

Treatments are given in order to increase the students' achievement from the pre-test. During the treatment, the writer and the collabolator observed the students' and teacher's activity.

During the game, students are allowed to look up dictionary and work in groups. Afterward, they submitted their work to the teacher. Then, the teacher asked them some words in the game which deals with the lesson and the topic. The teacher tested their pronounciations, meaning of the word, part of speech and making word into a sentence.

The teacher observed that there were some students find it difficult to find some words because of the complicated construction in the game. In addition, the writer found that there were many students answered in the word grid game were not dealing with the topics that the teacher taught. So, these problems should be solved for the next cycle.

\section{The Presentation of the Post-Test in the Second Cycle}

The Result of Post-Test in the First Cycle

It is expected that the students' score should be better than post-test of the first cycle. The writer found that the average score was 78.56 and the median was 76. So, half of the students had passed the KKM. The description of the data in the post-test of the second cycle is presented below:

Table 4: The Result of the Students' Post-Test of the Second Cycle

\begin{tabular}{cccc}
\hline Score Range & Level of ability & Frequency & Percentage \\
\hline $81-100$ & Excellent & 16 & $44.44 \%$ \\
$61-80$ & Good & 19 & $52.78 \%$ \\
$41-60$ & Mediocre & 0 & $0 \%$ \\
$21-40$ & Poor & 1 & $2.78 \%$ \\
$0-20$ & Very Poor & 10 & $0 \%$ \\
\hline
\end{tabular}


Table 4 above shows that the students' scores are improved. The students are mostly in the good level and excellent. Only 1 student remains at the poor level.

Table 5: General Description Of The Post-Testsin The First Cycle And The Second Cycle

\begin{tabular}{cccccccc}
\hline Test & Sample & mean & $\begin{array}{c}\text { Standard } \\
\text { Deviation r }\end{array}$ & $\begin{array}{c}\text { Standard } \\
\text { Erro }\end{array}$ & d.f & T test & t critical \\
\hline Pre-test & 36 & 63.67 & 6.46 & 01.08 & 35 & 13.79 & 2.457 \\
$\begin{array}{c}\text { Post-test } \\
\text { of first } \\
\text { cycle }\end{array}$ & & 78.56 & & & & & \\
\hline
\end{tabular}

To measure whether the treatment in the second cycle is successful or not, the t-test should be calculated. If the t-test is higher than $t$ critical, the treatment is successful. The table above shows that the t-test is 13.79 and $t$ critical 2.457. So, it can be inferred that the second cycle worked out well. The research to increase the students' vocabulary achievement by using word grid games is considered successful.

\section{CONCLUSION}

\section{The Observation Result of the Post-Test in the Second Cycle}

Reflecting to the Post-test in the first cycle, the writer improved a weakness with the construction of the word grid games that is considered as difficult for the students to deal with since there are many non-target vocabularies chosen by the students. So the writer decided to decrease the difficulty level.

After explaining the rules, the teacher started the game. The students seemed active during the game. The writer saw an improvement to the passive students who got difficulties at the first cycle, they were more active than before. The teacher got many feedbacks in return.

\section{The Personal Reflection}

In conducting this research the writer found out some strengths and weaknesses in using word grid games to increase the students' vocabulary achievement.

\section{The strengths are:}

- The students were active to be involved in the lesson.

- The students seem happy to participate in the lesson since it they consider it as a game.

- Some students could share their ideas to the others who need.

- The students did not feel like they were studying, but learning since they didn't have to memorize the vocabulary.

- The students had their knowledge enriched about important things about words, such as meaning, parts of speech, and pronunciation since they often look up their dictionaries. 


\section{The weaknesses that the writer found are:}

- Some students seemed confused how to play the game. It can be seen at the first cycle.

- The word grid games in the first cycle had some biased answers. In the other words, the games could not cover the vocabulary in the topics determined by the writer.

\section{REFERENCES}

Blake, J. 2009. Increasing Vocabulary Production through Explicit Vocabulary Instruction. Saint Paul, Minnesota: Hamline University.

Chodbury, Anindya Syam. 4 June 2010. Teaching Vocabulary in the ESL/EFL Classroom: Central Pedagogical Issues. ISSN 0974-8741.

Deesri, Angkana. 2002. Gams in ESL and EFL Class. The Internet TESL Journal, 8 (9), September.

Harris, D.P. 1969. Testing English as a Second Design and Statistics. New York: House Publisher.

Heaton, J. B. 1988. Writing English Language Test. London: Longman Inc.

Hughes, Arthur. Testing for Language Teachers. United Kingdom: Cambridge.

Lehr, F, Osborn, J and Hiebert, E.H.2004. A focus on Vocabulary. Pacific Resources for Education and Learning, ESo419. 